\title{
TUNNEPEILI - TUNNETILOJEN HEIJASTAJA MERKITYKSELLISISSÄ OPPIMISKOKEMUKSISSA
}

\begin{abstract}
Minkälaisia ovat merkitykselliset oppimiskokemukset ammattiin opiskelussa lähihoitajakoulutuksen aikana? Tähän kysymykseen hain vastausta haastattelemalla vanhustyön koulutusohjelman suorittaneita vastavalmistuneita lähihoitajia ja analysoimalla vastauksia. Artikkelissa tarkastellaan vanhustyötä hoivaamisena ja tunnetyönä. Lisäksi kirjoittaja kuvaa tutkimustuloksissa tunnepeiliä merkityksellisten oppimiskokemusten heijastajana.
\end{abstract}

\section{KATRI LUUKKA}

$\mathrm{S}$ uomessa tiedostetaan hyvin väestön ikääntyminen ja samalla sen tuomat taloudelliset haasteet suomalaiselle hyvinvointiyhteiskunnalle. Vanhusten hoitaminen on toistuvasti ollut esillä julkisessa keskustelussa lehdistössä ja televisio-ohjelmissa. Vanhuudesta on tehty meille ”yhteinen ongelma”, joka kosketta muita, muttei minua itseäni (Vakimo 2003).Vanhusten hoitamista pidetään salaperäisenä, koska ikääntyessään ihmiset menettävät fyysistä, henkistä ja sosiaalista toimintakykyään sekä samalla riippumattomuuttaan muista ihmisistä. Molander (2001) tuo esille vanhusten hoitajien työn "pettäneiden ruumiintoimintojen poistamisena muiden silmistä, josta intiimiytensä takia ei sovi puhua”. Myös Tedre (2001) kuvaa, että "hoivatyössä lika on läsnä sekä fyysisiin tiloihin tunkeutuvana tilana että ruumiin eritteinä. Ruumiin eritteet kuuluvat henkilökohtaisen ja intiimin alueelle, ne ovat kulttuurisesti kiellettyjä aiheita”. Edelliseen perustuen vanhusten hoitamista pidetään usein sekä fyysisesti että henkisesti raskaana hoitotyön osa-alueena. Myös tutkimuksissa on osoitettu, että vanhustyöntekijöillä on työhön väsymistä henkisenä uupumisena (Hyttinen ja Kangassalo 2002). Omalta osaltaan vanhusten hoitamiseen liittyvä julkinen keskustelu luo negatiivisia mielikuvia vanhustyöstä, joten ei ole yllättävää, etteivät lähihoitajaopiskelijat valitse mielellään viimeisen vuoden syventäviksi opinnoiksi vanhustyön koulutusohjelmaa (Luukka 2003).
Toisaalta vanhusten hoitaminen on myös antoisaa ja palkitsevaa, siitä saa elämäniloa ja voimaa itselle hoitajana. Koistinen (2003) ehdottaakin, että hoivasta puhuttaisiin niin, että se herättää positiivisia tunteita ja ajatuksia. Koistisen ehdotus tuntuu hyvältä ehdotukselta tähän aikakauteen, jossa vanhuksista yleensä puhutaan positiiviseen sävyyn vain vanhusten teemaviikkojen aikana. Vanhuksista positiiviseen sävyyn puhuminen

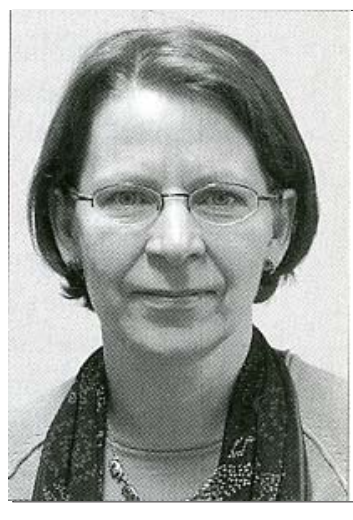

Katri Luukka tasapainottaisi nykyistä julkista keskustelua, jossa vanhukset on pelkistetty muuta yhteiskuntaa uhkaavaksi, jatkuvia vaatimuksia esittäväksi ryhmäksi.

\section{TUNTEET JA TUNNETILAT}

Tunnetta ja järkeä pidetään usein erillisinä, toisilleen vastakkaisina ja keskenään ristiriitaisina käsitteinä. Uudet kognitiiviset tunneteoriat (Niiniluoto1996) pitävät tunteita yhtenä tiedon muotona, jolloin myös emotionaalisuuden ja rationaalisuuden vastakkainasettelu raukeaa. Myös Damasio (1999, 281) kuvaa tietämisen ja tunteen läheistä yhteyttä seuraavasti: ”Tietoisuus tuntuu tunteelta, ja jos se tuntuu tunteelta, se voi hyvinkin olla tunne.” Tarkastelen tässä yhteydessä tun- 
teita (emootiot) osana ihmisen kognitiivista toimintaa, jolloin tunteet toimivat tiedonhankinnan keinoina ihmisen suhteesta itseensä ja tavoitteisiinsa. Tunteet toimivat ihmisen psyykkisen tasapainon säilyttämisen puolesta (Niiniluoto 1996). Ilo on merkki tavoitteiden saavuttamisesta, suru ja masennus epäonnistumisesta sekä pelko ympäristön koetusta uhkasta. Erilaisten määritelmien mukaan edellä mainitut ilo, suru ja pelko ovat niin sanottuja perustunteita. Perustunteiden, sekundaarien tunteiden tai tunnetilojen määrittelyt vaihtelevat paljon riippuen kirjoittajan teoreettisista lähtökohdista. Seuraavaksi muutama esimerkki tunteiden luokittelusta.

Esittelen tässä yhteydessä kolme esimerkkiä erilaisista tunteiden luokituksista. Damasio $(1999,54)$ jakaa tunteet kolmeen luokkaan: primaarit ja samalla universaalit emootiot (onnellisuus, surullisuus, pelko, viha, yllättyneisyys ja inho); sekundaarit eli sosiaaliset emootiot (nolous, mustasukkaisuus, syyllisyydentunto ja ylpeys) ja taustaemootiot (hyvänolontunne, pahanolontunne, tyyneys ja jännitys). Wager vuorostaan (1999) esittelee kahdeksan perustunnetta, jotka voidaan tunnistaa ihmisen kasvoilta ja olemuksesta kulttuurista riippumatta. Näitä perustunteita ovat 1) pelko tai kauhu 2) suuttumus tai raivo 3) ilo tai ekstaasi 4) suru tai epätoivo 5) hyväksyntä tai luottamus 6) inho tai vastenmielisyys 7) ennakointi ja 8) yllätys. Kolmanneksi Varilan $(1999,72)$ jaottelu, jossa perustunteita esitetään olevan kuudesta kymmeneen. Näitä perustunteita ovat ilo, yllättyneisyys, surullisuus, viha, epäluulo, halveksunta, pelko, ahdistus, ujous ja häpeä. Edellä kuvattujen perustunteiden lisäksi voidaan määritellä erikseen tunteet ja tunnetilat. Varila (1999, 69) erottaa tunteen (emootio) käsitteen tunnetilan (feeling state) käsitteestä seuraavasti: Tunnetila on yksilön kokemuksellisena tilana, joka tavallisesti koostuu useammasta tunteesta samanaikaisesti, se on myös kokijan itsensä havaitsema ja liittyy kokijan sisäiseen tilan muutokseen. Lisäksi tämä tila ei ole niin pitkäkestoinen, että se voitaisiin tulkita mielialaksi (mood). Tunnetila on yksilön arvio hänessä tietyllä hetkellä vaikuttavien tunteiden kokonaisuudesta. Näitä kolmea edellä esiteltyä erilaista tunteiden luokittelutapaa yhdistää se, että tunteissa nähdään olevan perustunteet, jotka tosin vaihtelevat. Päädyin tässä tutkimuksessa käyttämään tunnetila-käsitettä (Varila 1999), koska se kuvaa mielestäni parhaiten hoitajien kokemuksia hoi- totilanteiden herättämistä tunteista erityisesti vanhustyössä.

\section{TUNNETILOJEN ILMENEMINEN VANHUSTYÖSSÄ}

Käsittelen tässä tunnetiloja vanhustenhoidossa tunteiden ilmenemisenä. Käytän vanhustenhoidosta käsitettä vanhustyö, jolla tarkoitan koulutetun henkilöstön toteuttamaa hoitoa ikääntyneille ihmisille laitos- ja kotihoidossa. Vanhustyössä muodostuu hoitajan ja vanhuksen välille tunnetiloja vuorovaikutussuhteessa. Vanhustyössä ovat sekä hoitaja että vanhuspotilas läsnä vuorovaikutuksessa syntyneessä tunnetilassa. Hoitaessaan vanhusta hoitaja ei voi erottaa tunnetta ja havaitsemista eikä havainnon kohdetta koskevia ennakkokäsityksiään toisistaan. Tunnetila liittyy hoitajan tapaan nähdä ja kokea vanhuspotilas.

Tunnetila antaa hoitajalle keskeistä tietoa hänen suhteestaan vanhukseen. Tunnetila ei ainoastaan informoi hoitajaa vaan se myös antaa tietoa hoitajasta ja hänen vuorovaikutussuhteestaan ulospäin muille. Tunnetila opastaa hoitajaa toimimaan omalta kannaltaan oikealla tavalla suhteessa vanhuspotilaaseen. Tämän vuoksi hoitajan on tarpeellista oppia identifioimaan omia tunteitaan, tulkitsemaan muiden tunteita ja lisäksi tunnistamaan muiden ilmaisemien tunteiden kohteita. (Lowenberg 2003, Yorks \& Sharoff 2001.)

Tunnetilat voidaan myös sitoa normeihin, mikä tekee niistä ulkoa ohjailtavia. Tällöin esimerkiksi rituaalinen toiminta voi olla normi ja samalla se on keino virittää haluttuja tunnetiloja. Toiminnan rituaalisointi on myös menetelmä kontrolloida tunnetiloja. Vanhustyössä on erilaisia rituaaleja ja kirjoittamattomia sääntöjä siitä, kuinka tunteita on sallittua osoittaa ammatillisessa vuorovaikutussuhteessa. Esimerkiksi aamupesut ovat keinoja toiminnan kautta kontrolloida omia tunteita. Tällöin hoitajan toiminta vanhustyössä voi olla hyljeksivä, kylmästi rutiininomainen, robottimainen tai kasettimainen kuten Liukkonen (1990) on omassa väitöskirjassaan havainnut dementoituneiden potilaiden hoitajien toimivan. Dementoituneiden potilaiden hoitajat toimivat myös taitavasti (Liukkonen 1990). Hoitaja ilmaisee omalla toiminnallaan tunnetilojaan heikosti tai vahvasti, jolloin hän viestittää omistautumisen luonteestaan. Näin toimiessaan hoitaja ilmaisee sekä itselleen että muille hoitotilanteessa, miten vakavasti hän suhtautuu hoitamiseen. 


\section{TUNNETYÖN OPISKELU LÄHI- HOITAJAKOULUTUKSEN AIKANA}

$\mathrm{T}$ lunteiden omistautumisen lisäksi vanhustyötä voidaan tarkastella tunnetyönä, jossa hoitaja joutuu muun muassa kontrolloimaan, esittämään, peittämään ja työstämään omia tunteitaan. Hoitosuhteessa tunnetyötä tekeviltä hoitajilta odotetaan tunneilmaisun kontrollia ja myönteisiä tunneilmaisuja. Tämä merkitsee sitä, että tunnetyöhön kuuluu negatiivisten tunteiden (viha, ärtymys, kyllästyneisyys jne.) työstäminen pois tai ainakin niiden peittäminen. Tunnetyöhön kuulu myös positiivisten tunteiden esittäminen, elleivät ne tule "luonnostaan” esille (Ilmonen 1999). Ahokkaan (1998) mukaan tunteet eivät ole jotain, joita ilman voisimme käskystä olla, vaan ne liittyvät ihmiseen "kuin hengitys". Tunteiden ilmaisu ja tunnetilojen käsittely on osa ammattitaitoa ihmissuhdetyössä, mutta auttamissuhteen ollessa kyseessä hoitaja joutuu hoitotilanteessa säätelemään, miten hän ilmaisee tunteitaan hoidettavalle, joka on usein vanhuspotilas. Vanhustyössä kuten hoitotyössä yleensäkin tunnetyön tarkoituksena on vaikuttaa hoitotilanteessa siten, että vuorovaikutussuhteessa muodostuu myönteinen tunnetila niin hoidettavalle kuin hoitajalle.

Forsbergin (2002) mukaan opiskelijoiden tunnetyö liittyy ammattiin kasvamisen prosessiin, jonka avaaminen voi olla hyödyllistä paitsi heille itselleen myös muille aloittelijan rooliin joutuville. Tunnetyön ammattilaiseksi hoitajat opiskelevat koulutuksen aikana erityisesti työssäoppimisjaksojen aikana, jolloin opiskelijat toimivat yhdessä hoitohenkilökunnan kanssa todellisissa hoitotilanteissa. Työssäoppimisjaksojen aikana opiskelijan ammatillinen osaaminen kehittyy ja ammatti-identiteetti muodostuu. Työssäoppimisjaksolla ohjaava hoitaja toimii roolimallina opiskelijalle. Hoitaja on opiskelijalle esikuva, johon opiskelija haluaa tai ei halua samaistua. Tällöin hoitajan oma roolimalli on opiskelijalle myös esimerkki "tunnetietoiseen työhön opettelemisesta” (Molander 2003, 169). Yhteisökasvatuksen (Kaipio 1999, 164) käsityksen mukaan sosialisaatio on vuorovaikutusprosessi, jossa myös kasvatettavat voivat sosiaalistaa kasvattajia. Näin ollen työssäoppiminen voidaan myös nähdä kaksisuuntaisena, tällöin opiskelijat ja opettajat molemmat oppivat ohjaustilanteissa. (De Weerdt \& Bouwen 2002, Guile \& Griffiths
2001). Koulutuksen aikana tapahtuva osaamisen kehittyminen, ammattiin sosiaalistuminen ja ammatti-identiteetin muodostuminen jatkuu edelleen työssä valmistuneena lähihoitajana.

\section{TUTKIMUKSEN TOTEUTTAMINEN}

Väitöskirjassani selvitin, minkälaisia olivat merkitykselliset oppimiskokemukset ammattiin opiskelussa lähihoitajakoulutuksen aikana ja vanhustyössä. Tässä artikkelissa kuvaan lähihoitajakoulutuksen aikaisia merkityksellisiä oppimiskokemuksia. Tutkimukseen osallistui 17 keväällä 2002 valmistunutta lähihoitajaa, jotka kaikki olivat suorittaneet viimeisen vuoden aikana vanhustyön koulutusohjelmaopinnot. Haastatteluteemana oli merkitykselliset oppimiskokemukset lähihoitajakoulutuksen aikana. Tein haastattelut loka- ja marraskuussa 2002. Haastattelut kestivät keskimäärin tunnin. Lyhyin haastattelu kesti 46 minuuttia ja pisin haastattelu 78 minuuttia. Sanatarkasti aukikirjoitettua haastattelumateriaalia kertyi yhteensä 227 sivua.

Analysoin tutkimusaineiston aineistolähtöisesti laadullisella sisällönanalyysin menetelmällä (Chi 1997, Kyngäs \& Vanhala 1999, Miles \& Huberman 1994, Tuomi \& Sarajärvi 2002). Aloitin aineiston analysoinnin sanatarkasti aukikirjoitettujen tekstien toistuvalla lukemisella. Samalla kun luin tekstejä, piirsin käsitekarttoja, jotka muodostuivat aineistosta. Luin alkuperäisiä tekstejä läpi uudestaan kaksi kysymystä mielessäni: mitä tämä on ja mitä tämä edustaa. Tämän jälkeen luin tekstit uudestaan ja nimesin alkuperäisilmaisut (haastateltavien tekstit) pelkistetyiksi ilmaisuiksi (Tuomi \& Sarajärvi 2002), tämä on tutkijan antama uusi käsite alkuperäiselle ilmaisulle. Seuraavaksi yhdistin samankaltaisia ominaisuuksia yhdistävät pelkistetyt ilmaisut alaluokiksi ja yläluokiksi. Samankaltaisia ominaisuuksia sisältävät ala- ja yläluokat auttoivat löytämään aineistosta merkityksellisiä oppimiskokemuksia kuvaavan pääluokan, joka on tunnepeili.

\section{MERKITYKSELLISET OPPIMISKOKEMUKSET}

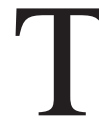

unnepeili käsitteenä muodostui aineiston analyysin aikana, kun havaitsin, että lähihoitajat kuvasivat itselleen merkityksellisiä oppimiskokemuksia tunnetiloina erilaisissa asiayhteyksissä (kuvio 1). 


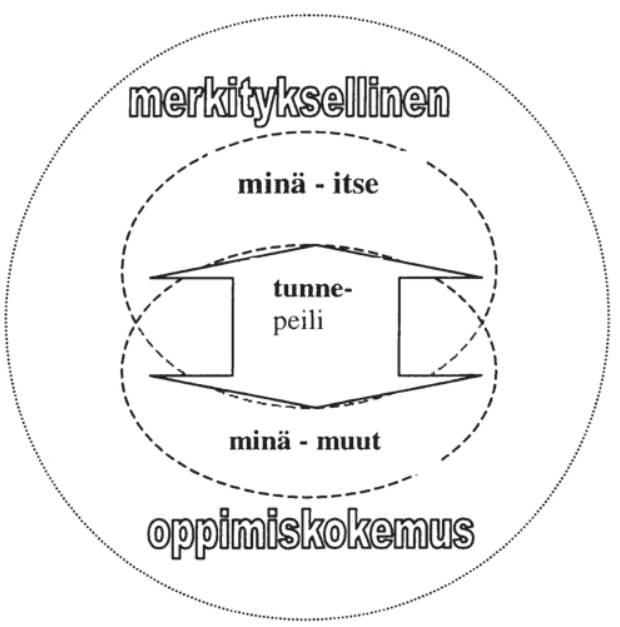

Kuvio 1. Tunnepeili merkityksellisen oppimiskokemuksen heijastajana

Lähihoitajien kuvauksissa merkitykselliset oppimiskokemukset tunnepeileinä muodostuivat ammattiin opiskelussa sekä oman itsen kanssa käytynä sisäisenä keskusteluna että vuorovaikutuksessa muiden kanssa. Lähihoitajat kertoivat, että heistä esimerkiksi tuntui hyvältä, helpottavalta, hävettävältä, harmittavalta, henkisesti raskaalta, riittämättömältä, hämmentävältä, turhauttavalta, vaikealta, ylpeältä ja onnistuneelta erilaisissa opiskelu- ja työtilanteissa.

\section{MINA - ITSE}

Lähihoitajien kertomuksissa tunnepeili ilmaisi, kuinka he kävivät itsensä kanssa sisäistä keskustelua opiskeluun ja hoitotyöhön liittyvistä asioista tunnetiloina. Seuraavaksi esimerkki siitä, kuinka lähihoitaja kävi oman itsensä kanssa sisäistä keskustelua tunnetilasta, joka muodostui työssäoppimisen jaksolla. Kursiivi teksti on lähihoitajien (H1-H17) alkuperäistä puhetta haastattelutilanteessa.

”Ensimmäisen kerran meinas se koulunkäynti pysähtyä siihen mielenterveysjaksoon. Me ei saatu valita paikkoja, koska "- - - "ssa oli niin vähän, että oli mentävä sinne, minne käskettiin. Niin se oli sellanen pitkäaikaismielenterveyspotilaitten plus kehitysvammaisten paikka, se oli just sellanen ...en ollu koskaan nähny enkä oikeestaan kuullutkaan mistään mielenterveyspotilaista enkä hirveesti kehitysvammasistakaan. Se oli just niinku jostain kauhufilmistä, kaikki ovet lukossa ja ne istuu alasti nurkassa ja huutaa... mie olin siellä kolme päivää ja mie olin siellä kolme päivää niin kauhusta kankeena, ett mä en tienny itkeekö vai nauraa ja sit mie menin koululle ja sanoin, että nyt loppuu miun koulu tähän, jos ei saa vaihettua tuota harjottelupaikkaa, ett sillon tuntu, ettei osaa ollenkaan olla tommosessa paikassa, mut ei nyt tuntuis niin kauheelta ehkä (H3).”

Tässä esimerkissä työpaikka ja työnluonne aiheuttavat voimakkaan tunnereaktion. Lähihoitaja ilmaisee itselle merkityksellistä oppimiskokemusta työssäoppimisen jaksolla tunnepeilinsä kautta lähinnä kauhukokemuksena. Hän toteaa itseään "peilaten”, että silloin (opiskelijana) tuntui, ettei osaa olla tuollaisessa työpaikassa, mutta ehkä nyt (valmistuneena lähihoitajana) ei enää tuntuisikaan kauhealta, "ehkä". Kuvauksessa tulee esille oman minän vertaus itseen eri aikajaksona. Hän koki opiskelijana ollessaan hoitotilanteen kauhistuttavana. Haastattelutilanteessa hän myöhemmin jo valmistuneena lähihoitajana katselee koulutuksen aikaista kokemustaan uudenlaisesta itsestä käsin, kyseinen hoitamisen kokemus ei ehkä enää tuntuisikaan niin kauhistuttava kuin opiskeluaikana.

\section{MINÄ - MUUT}

Lähihoitajat kuvasivat tunnepeilinsä kautta merkityksellisiä oppimiskokemuksiaan oman itsensä kanssa käymän sisäisen keskustelun lisäksi peilaamalla tai heijastamalla itseään muihin henkilöihin kuten toisiin opiskelijoihin, työpaikan ohjaajiin, potilaisiin, opettajiin ja perheenjäseniin. Ensiksi esimerkki siitä, kuinka toinen opiskelija toimi tunnepeilinä koulutuksen aikana. "Alkuun se (työssäoppimisjakso) vähän jännitti, koska mä aattelin, että tuleeko siinä jonkin tasosta kilpailua tai just ku tää oli tämmönen virikkeellinen paikka ja molemmat on kuitenkin aika tämmösiä kunnianhimoisia ihmisiä, niin mä aattelin, et jos siinä tulee jotain tämmöstä kilpailua...(H17)."

Toisessa esimerkissä työssäoppimisjakson ohjaat toimivat tunnepeilinä lähihoitajalle. "Mulla oli ne kolme ohjaajaa...niin totanoin niin... niin sanotaan, että yks niistä oli erittäin ihana, et tota ja oli ne varmaan ihan ihanii ne...me ei vaan ehkä ymmärretty toisiamme sit tarpeeks hyvin, mutta tota...ihan sitten tän yhden kanssa sain sitten keskusteltua ja, et se monesti sanokin, et älä välitä, että nää on vaan sen tyylisiä ja tämmöstä, että...et niiltä tulee, ja sit se kova kie- 
lenkäyttö, et vaikka mä nyt oon ravintolan ihminen, niin oon tottunu semmoseen karskiin kielenkäyttöön, mut tota sit kun siinä oli kuitenkin niitä potilaita ja potilaiden läsnä puhuttiin kaiken näköstä, niin se järkytti mua ihan hirveesti, et mä kävin siinä mun kirjallisessa osiossakin läpi näitä tunteita, mitä mussa herätti se...se, et vaikka se kasvattikin mua, niin totanoin kuiteski siinä jäi joku paha mieli mulle, että...et se paikka, missä mä olin, ni en kyllä ikinä menis töihin, vaikka ois viimenen työpaikka, vaikka siel on varmasti muita osastoja ihan ihania...siellä paikassa (H15).”

Kolmannessa esimerkissä lähihoitajan opettaja toimi tunnepeilinä seuraavasti. "No minun ensimmäinen tuuttori (opettaja) oli aivan mahtava tuuttori, et tuntu et se ei niinku ei kertaakaan silleen luovuttanu et ei noista tuu mitään, ku nuo ei tee tehtäviään, et se yritti koko ajan selittää meille niinku, että itteä varten te täällä ootte justiin, et sillon se ei vaan jotenkin menny päähän, et se ja hän muisti aina sitten, vaikka hän toisiin hommiin siitä tuutorin hommista... ettei jatkanutkaan, niin silti hän aina muisti onnitella, jos hän oli huomannu et nyt on taas joku tehtävä tehty niin aina hän tuli käytävälle ja sanoi onneksi olkoon ja kuitenkin vähän tuntu, et hän seuras sen oman ryhmän opiskelua, vaikka oli uus tuuttori jo... näin jotenkin hän on jääny niinku... hän oli hirveän tärkeä opettaja mulle (H6).”

Neljäntenä on esimerkki siitä, kuinka vanhuspotilaat toimivat tunnepeilinä työssäoppimisen jaksoilla. "No tota... mä en oo koskaan tehny laitostyyppistä niinku " - _ - " sairaala semmosta työtä aikaisemmin, että sitten kun selvisin niistä alkujärkytyksistä, huomasin, että se on kyllä niin antoisaa puuhaa, että jotenkin sitä halus vaan tehä ja en mä tiiä... niihin vanhuksiin vaan jotenkin rakastu (naurua)... et voisko siitä käyttää sitä... et kyl se on niin raskasta, mut kyl se on ihanaa ja palkitsevaa työtä (H5).”

Viimeisenä esimerkkinä on perheenjäsenten toimiminen tunnepeilinä lähihoitajalle koulutuksen aikana. "... ehkä siihen (työssäoppimiseen) vaikutti kans se, kun just oli menettäny mumminsa ja kokenu just kolmannen avioeron (vanhempien), mut kuitenkin, sit ku yrität tukee pieniä siskojas siinä... ala-asteikäsii, ni yrität ite olla vahva ja yrität opiskella (H16).”

Ensimmäisessä esimerkissä opiskelija koki työssäoppimisjakson kilpailutilanteena toisen opiskelijan kanssa. Toisessa esimerkissä opiske- lija koki ohjaajien toiminnan ristiriitaisina tunteina työssäoppimisenjaksolla. Kolmannessa esimerkissä opettajan toiminta jäi mieleen positiivisena tunnekokemuksena. Neljännessä esimerkissä vanhukset omalla olemuksellaan herättivät halun hoitaa vanhuksia. Viidennessä esimerkissä opiskelija koki omassa elämäntilanteessa vahvoja tunnetiloja työssäoppimisjakson aikana.

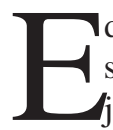

dellä olevat esimerkit kuvaavat merkityksellisiä oppimiskokemuksia tunnetiloina, joita tapahtuu ammattiin opiskelussa arjen jokapäiväisissä tilanteissa koulutuksen aikana. Näissä tunnetiloissa lähihoitajat tarkastelevat tunnepeilinsä avulla itseään suhteessa toisiin henkilöihin opiskelu- ja työtilanteissa. Lähihoitajat työskentelevät hoitotyössä hoitaen asiakkaita/ potilaita, jotka ovat pääosin vanhuksia. Hoitotyössä hoitajan tärkeimpänä ”työkaluna” pidetään usein hoitajan omaa persoonaa, joka on jokaisella henkilöllä ainutkertainen ja yksilöllinen. Tutkimukseni tuloksena nousee esille oman persoonan muodostuminen tunnetiloina suhteessa muihin henkilöihin itselle merkityksellisissä opiskelu- ja työtilanteissa. Tutkimuksen tulosten perusteella voisi lähihoitajaopiskelijan ja myös valmistuneen lähihoitajan yhtenä tärkeänä työkaluna pitää tunnepeiliä, jonka avulla hoitaja ikään kuin jatkuvasti määrittelee itseään omana persoonana suhteessa muihin henkilöihin.

\section{POHDINTAA}

Tutkimuksessa muodostuneella tunnepeili-käsitteellä on yhteneväisyyttä Silkelän (1999, 43-44) tekemään tarkasteluun persoonallisesti merkittävistä oppimiskokemuksista opettajaopiskelijoilla. Silkelän mukaan opiskelijoiden persoonalliset elämänhistoriat ovat eräänlaisina "peilikuvina” ja opiskelijoiden rooli-identiteetit ovat "tulkitsevia linssejä”. Myös tutkimukseni lähihoitajat "peilasivat” itseään omassa sisäisessä keskustelussaan ja he myös peilasivat itseään muihin henkilöihin erilaisissa opiskelutilanteissa. Itsen kanssa käytävää sisäistä keskustelua voidaan kutsua Hubert Hermansin mukaan itsen dialogiksi (dialogical self) (Ligorio 2003), jossa itse (extended self) muodostuu laajennettuna sosiaalisissa suhteissa muiden ihmisten kanssa. Lähihoitajien merkityksellisissä oppimiskokemuksissa keskeiseksi muodostuneessa tunnepeili-käsiteessä on mukana edellä kuvattua itsen dialogia sekä laa- 
jennettua dialogia itsen ja muiden kanssa. Edellä olevaa voidaan nimittää myös sosiaaliseksi identiteetiksi, joka muodostuu työpaikalla merkitysvälitteisesti vuorovaikutustilanteissa (ErikssonPiela 2003, 28-29).

Työssäoppimisjaksot näyttävät olevan keskeisessä asemassa muodostamassa merkityksellisiä oppimiskokemuksia lähihoitajille koulutuksen aikana. Tulos on yhtenevä Kallioniemen ja Kaivolan (2003) tutkimukseen aineenopettajakoulutuksesta ja Silkelän (1999) tutkimukseen luokanopettajakoulutuksesta. Myös niissä opiskelijoiden merkitykselliset oppimiskokemukset liittyivät koulutuksen aikaiseen työssäoppimiseen (opetusharjoittelu). Työssäoppiminen on erittäin merkityksellinen lähihoitajakoulutuksen aikana myös sen vuoksi, että lähihoitajaopiskelijat kokevat työssäoppimisen motivoivana (Huhtala \& Luukka 2003). Haastattelussani lähihoitajat muistivat yksityiskohtaisesti työssäoppimisjaksoihin liittyviä merkityksellisiä oppimiskokemuksia. Toisaalta tämä ei ole yllättävää, koska aidoissa hoitotilanteissa opiskelijan ammatillinen osaaminen kehittyy. Opiskelija sosiaalistuu ammattiin ja hänelle muodostuu ammatti-identiteetti. Todellisissa hoitotilanteissa hoitohenkilökunta toimii opiskelijoiden ohjaajina, mutta he ovat sammalla kollegiaalisia roolimalleja, joihin opiskelijat haluavat tai eivät halua samaistua.

Edellisen lisäksi hoitohenkilökunta on tärkeässä asemassa myös sen vuoksi, että opiskelijat tekevät viimeisen vuoden koulutusohjelmaopintovalintoja sillä perusteella, minkälaisia kokemuksia heillä on erilaisilta sosiaali- ja terveysalan työpaikoilta koulutuksen alkuvaiheen opinnoissa. Tutkimukseen osallistuneilla lähihoitajilla oli sekä positiivisia että negatiivisia tunnetiloja muistoina työssäoppimisjaksoilta. Voimakkaat negatiiviset tunteet ja niiden käsittelemättä jättäminen työssäoppimisjaksojen aikana voivat vaikuttaa siihen, minkälaisia valintoja opiskelijat tekevät koulutuksen aikana (Lyth 2000). Vanhustyöhön ennustetaan melkoista työvoimapulaa lähitulevaisuudessa, samalla vanhustyö ei ole suosituin vaihtoehto lähihoitajaopiskelijoiden keskuudessa (Luukka 2003). Näin ollen erityisesti vanhustyön työssäoppimispaikkojen oppimiskokemuksilla koulutuksen aikana näyttää olevan vaikutusta siihen, valitsevatko lähihoitajaopiskelijat vanhustyön viimeisen vuoden koulutusohjelmaopinnoiksi.
L opuksi muutamia kokoavia ajatuksia "tunnetyöläisten” kouluttajille ja hoitoyhteisöille.

1) Lähihoitajakoulutuksen valtakunnallinen opetussuunnitelma kaipaa mielestäni uudelleen tarkastelua siltä osin, että valmiudet omien tunteiden tunnistamiseen ja käsittelyyn tulisi asettaa tavoitteeksi lähihoitajakoulutuksen alkuvaiheen ammatillisiin perusopintoihin ja jokaiseen lähihoitajakoulutuksen koulutusohjelmaan. Nykyisessä opetussuunnitelmassa (Sosiaali- ja terveysalan perustutkinto 2001) valmiudet käsitellä auttamis- ja hoitotyössä omia tunteita mainitaan vain mielenterveys- ja päihdetyön koulutusohjelmassa.

2) Hoitohenkilöstö tekee usein kolmivuorotyötä, joten koko henkilöstön osallistuminen samanaikaisesti työyhteisössä käytävään keskusteluun on usein mahdotonta. Tähän pulmaan tietoverkkoympäristö mahdollistaa ajasta ja paikasta riippumattoman keskustelun, jossa on myös mahdollisuus rakentaa omaa identiteettiään (Murray 2000). Verkkokeskustelussa kuitenkin menetetään mahdollisuus ihmisten väliseen sosiaaliseen kanssakäymiseen, jossa nonverbaalisella viestinnällä (mm. ilmeet, eleet, hymyily, itku tai nauru) on merkittävä osuus tunteiden ilmaisussa, joten ”tunnetyöläisille” verkkokeskustelu mahdollistaa vai osittain tunnetilojen käsittelyn yhdessä muiden kanssa.

3) Myös suomalaiset hoitoyhteisöt ovat muuttumassa useita eri kansallisuuksia edustaviksi monikulttuurisiksi työyhteisöiksi. Hoitoyhteisöissä kohtaavat kulttuureiden erilaiset tunneilmaisutavat, joten meille suomalaisille "tunnetyöläisille” on avautumassa mahdollisuus oppia sosiaalisessa vuorovaikutuksessa muilta kulttuureilta tunneilmaisun moninaisuutta.

\section{LÄHTEET}

Ahokas, M. (1998). Tunnetyö. Teoksessa Lahikainen, A. R. \& Pirttilä-Backman, A-M. (toim.) Sosiaalinen vuorovaikutus. Rauni Myllyniemen juhlakirja. Otava.

Chi, M. T. H. (1997). Quantifying Qualitative Analyses of Verbal Data: A Practical Guide. The Journal of the Learning Science 6 (3), 271-315.

Damasio, A. (1999). Tapahtumisen tunne, miten tietoisuus syntyy. Terra Gognita Oy. 
De Weerdt, S. \& Bouwen R. (2002). Developing Professional Learning Environments: Model and application. Studies in Continuing Education 2 (1), 25-38.

Eriksson-Piela, S. (2003). Tunnetta, tietoa vai hierarkiaa? Sairaanhoidon moninainen ammatillisuus. Acta Universitatis Tamperensis: 929.

Forsberg, H. (2002). Tunteet - sosiaalityötä harjoittelevan häpeä? Aikuiskasvatus 4, 295-305. Guile, D. \& Griffiths, T. (2001). Learning Through Work Experience. Journal of Education and Work 14 (1), 113-131.

Huhtala, S. \& Luukka, K. (2003). "Se hoitamisen jutska"- opiskeluun motivoituminen lähihoitajakoulutuksen alussa. Esitys. Kasvatustieteen päivät. Helsingin yliopisto 20. -21.11.2003.

Hyttinen, H. \& Kangassalo, R. (2002). Vanhustyöntekijät - näkemyksiä vanhustyöstä ja sen kehittämisestä. Gerontologia (4), 190-197.

Ilmonen, K. (1999). Työelämä ja tunteet. Teoksessa Näre, S. (toim.) Tunteiden sosiologiaa 2. Historiaa ja säätelyä. Suomalaisen kirjallisuuden seura, Tietolipas 157, 299-324.

Kaipio, K. (1999). Kasvattava yhteisö. Gummerus. Kallioniemi, A. \& Kaivola, T. (2003). Persoonallisesti merkittävät oppimiskokemukset ja aineenopettajakoulutus. Arja Virta ja Outi Marttila (toim.) Opettaja, asiantuntijuus ja yhteiskunta. Ainedidaktiikan symposium 7.2.2003. Turun yliopiston kasvatustieteen julkaisuja B:72.

Koistinen, P. (2003). Hoivan arvoitus. Vastapaino.

Kyngäs, H. \& Vanhala, L. (1999). Sisällön analyysi. Hoitotiede (11), 3-12.

Ligorio, B. (2003). Dialogical Self at School: Interview to Hubert Hermans. European Journal of School Psychology (1), 119-129.

Liukkonen, A. (1990). Dementoituneen potilaan perushoito laitoksessa. Turun yliopiston julkaisuja. Sarja C:81.

Lowenberg, J. S. (2003). The Nurse-Client Relationship in a Stress Management Clinic. Holistic Nursing Practice 17 (2) 99-109.

Luukka, K. (2003). A Study on Practical Nurses' Personally Significant Learning Experiences. Konferenssiesitys. $10^{\text {th }}$ Bienneal Conference of European Association for Research on Learning and Instruction. 26-28.8.2003, Padova, Italia.
Lyth, I. M. (2000). Social Systems as a defense against anxiety. duGay, P. Evans, J.\& Redman, P. (edit.) Identity: a reader. Sage Publications. 163-181.

Miles, M. B. \& Huberman, A. M. (1994). Qualitative data analysis. An Expanded sourcebook. Second edit. Sage Publications.

Molander, G. (2003). Työtunteet - esimerkkinä vanhustyö. Työterveyslaitos.

Molander, G. (2001). Vanhuuttaan rappeutuva ruumis luonnon ja kulttuurin kohtaamispaikkana. Gerontologia (2), 125-135.

Murray, B. (2000). A mirror on the self. http:// www.apa.org/monitor/apr00/mirror.html.

Niiniluoto, I. (1996). Tunne ja tieto. Teoksessa Niiniluoto, I. \& Räikkä, J. (toim.) Tunteet. Yliopistopaino. 109-117.

Silkelä, Raimo. (1999) Persoonallisesti merkittävät oppimiskokemukset. Tutkimus luokanopettajiksi opiskelevien oppimiskokemuksista. Kasvatustieteellisiä julkaisuja n:o 52. Joensuun yliopistopaino.

Tedre, S. (2001). Hoiva ja ruumiillisuus. JANUS. Sosiaalipolitiikan ja sosiaalityön tutkimuksen Aikakauslehti 9 (1), 178-188.

Tuomi, J. \& Sarajärvi, A. (2002). Laadullinen tutkimus ja sisällönanalyysi. Gummerus.

Vakimo, S. (2003). Vanhuudesta on tehty yhteinen ongelma. Helsingin Sanomat. 8.10.2003.

Varila, J. (1999). Tunteet ja aikuisdidaktiikka. Tunteiden aikuisdidaktisen merkityksen teoreettinen ja empiirinen jäljitys. Joensuun yliopisto. Kasvatustieteiden tiedekunnan tutkimuksia n:o 74.

Wager, M. (1999). Tutkijuus ja tunteet. Teoksessa Näre, S. (toim.) Tunteiden sosiologiaa 2., Historiaa ja säätelyä. Suomalaisen kirjallisuuden seura, Tietolipas 157, 325-342.

Yorks, L., \& Sharoff, L., (2001) An Extended Epistomology for Fostering Transformative Learning in Holistic Nursing Education and Practice. Holictic Nursing Practice 16 (1), 2129.

Artikkeli saapui toimitukseen 28.4.2003. Se hyväksyttiin julkaistavaksi toimituskunnan kokouksessa 13.2.2004. 